\title{
Construction Industry and Payment Discipline in the Czech Republic
}

\author{
Lucie Kureková - Pavlina Hejduková*
}

\begin{abstract}
:
The paper deals with payment discipline in the building industry in the Czech Republic. The aim of this paper is to identify, compare and evaluate the financial situation of building companies with different payment practices in the Czech Republic in the period 2010 - 2014. The paper uses enterprise and statistical methods. The payment discipline of companies is expressed by a payment index, which is constructed by Bisnode. The results are based on analysis of 1374 companies which are operated in the building industry. The analysis shows that payment habits increase with higher index IN05, Taffler's model, index IN99 and with larger size of the firms. Payment habits of building companies are very good. However, about $2 \%$ of solvent companies have poor payments habits.
\end{abstract}

Key words: Construction industry; Payment discipline; Payment index; Bankruptcy models; Companies.

JEL classification: G31, G32, G33, L74, M21.

\section{Introduction}

The construction industry is one of the most important and traditional sectors of the national economy of the Czech Republic. The construction industry is defined by a wide range of customers; from individuals, families, businesses to the state. Just the connection between the state and the construction industry is often discussed as an issue of public procurement. The building market is capitalintensive and typically yields a slow turnover. It is possible to characterize the contracts realized on the building market as complicated. This is mainly due to the fact that we can find a variety of investors in the building market. (Pleskač, Soukup, 2001)

The financial management of the building companies and their payment discipline have also some peculiarities. This fact is caused by the specific characteristics of the building market. As we know, payment discipline can be defined as a set of indicators that reflect the payment behaviour of individual entities' fulfilment of

Lucie Kureková; University of Economics in Prague, Faculty of Economics, Department of Economics, Winston Churchill Square 4, 13067 Prague 3, Czech Republic, <xkurl06@vse.cz>. Pavlína Hejduková; University of West Bohemia, Faculty of Economics, Department of Finance and Accounting, Univerzitní 8, 30614 Pilsen, Czech Republic, <pahejdu@kfu.zcu.cz>.

This paper has been prepared under financial support of the project SGS-2015-019 The Impacts of Current Legal, Tax, Accounting and Social Changes on Private Businesses and Public Sector in the Context of Recodification of Private Law at the University of West Bohemia, Faculty of Economics, which authors gratefully acknowledge. 
financial liabilities. Payment discipline gives evidence of how many days after maturity or before maturity the entity pays its liabilities, or what is the usual maturity of the sector or the state. (Perthen, 2015)

Payment discipline of the Czech companies is below the European average and is still improving. (Machková, 2015)

We can see an improvement in payment discipline of building companies in the Czech Republic. As stated by Bisnode (2014), the average time of overdue invoices in the construction industry is longer than the overall average in the Czech Republic. Specifically: the construction industry in the Czech Republic has invoices 15 days after the due date; a total average of the Czech Republic is 10 days after the due date.

The aim of this paper is to identify, compare, and evaluate the financial situation of building companies with different payment practices in the Czech Republic in the period $2010-2014$, using enterprise data and statistical methods. The structure of the paper is as follows: literature review (relating to construction industry and its specifics), data and methodology (using the secondary data and statistical hypothesis testing), and results (evaluation of the analysis). The results are based on an analysis of data on payment discipline among 1374 Czech companies in the construction industry using three bankruptcy models. The conclusion is drawn by the synthesis method.

\section{Construction industry and its specifics}

\subsection{Construction industry}

The construction industry is very different from other sectors of the national economy. The specifics of the building sector are the especially seasonal nature of production, depending on the natural conditions, the length of the production cycle, the volume of intermediate consumption in production, the mobility of place of production or the time of commitment of resources. As reported Atallah (2006), the building sector has to deal with constantly changing external factors.

The external factors influencing the building market are shown in Fig. 1. 


\section{Fig. 1: Factors influencing the building market}

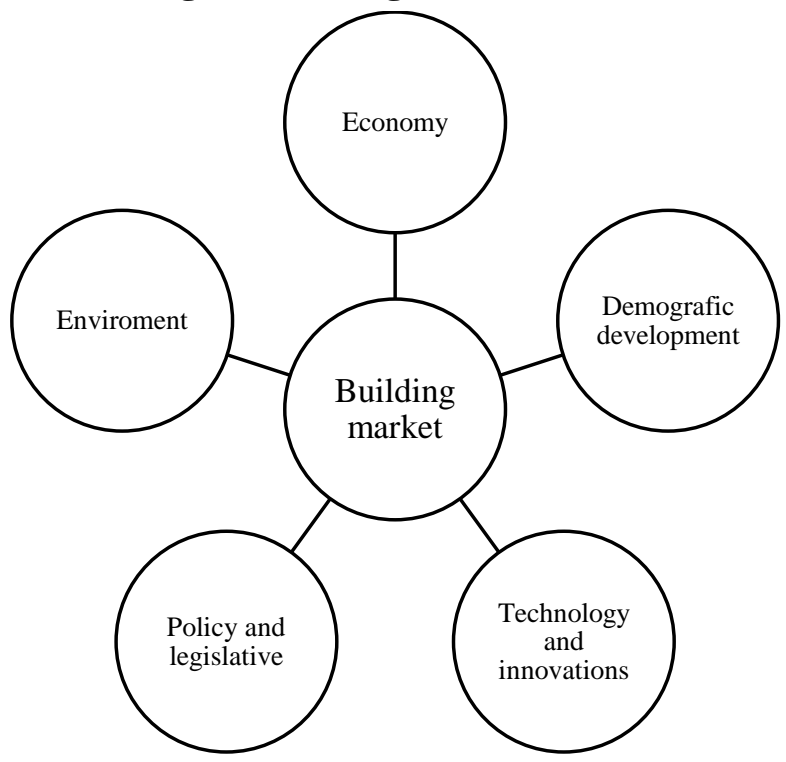

Source: authorial compilation based on Pleskač, Soukup (2001).

The construction industry is strongly dependent on the overall economy. Often this industry is defined as an indicator of the national economy. The reason for this fact is that according to the construction industry we can predict the development of the whole macroeconomic situation - the construction industry is one of the first sectors which will be effected by a recession, which means a decline in demand, or will be one of the first which will be effected by a boom in the form of an increase in orders (Linkeschová, 2005). The construction industry is often affected by foreign actors (see, for example McGeorge, Zou and Palmer, 2013), call as the driving force of the economy. Technological changes and innovations also have impacts on the construction industry.

Another significant impact on building sector has been the demographics development which is related with a potential demand for building work in certain segments of the building market (such as for living).

The political and legislative aspects related to the building market include general business conditions, the law on public procurement, law on landscape planning, building code etc. Having an increasing impact in the building market is also environmental factors or environmental protection in the implementation of the building. (Pleskač, Soukup, 2001) 
Kureková, L. - Hejduková, P.: Construction Industry and Payment Discipline in the Czech Republic.

\subsection{Development of the construction industry in the Czech Republic}

As mentioned above, the construction industry is an important part of the national economy and the construction industry is a significant component of the GDP. The share of the construction industry of GDP is shown in Tab. 1.

Tab. 1: The construction industry as a share of GDP in years $2007-2014$

\begin{tabular}{lcccccccc}
\hline Years & $\mathbf{2 0 0 7}$ & $\mathbf{2 0 0 8}$ & $\mathbf{2 0 0 9}$ & $\mathbf{2 0 1 0}$ & $\mathbf{2 0 1 1}$ & $\mathbf{2 0 1 2}$ & $\mathbf{2 0 1 3}$ & $\mathbf{2 0 1 4}$ \\
\hline $\begin{array}{l}\text { Construction } \\
\begin{array}{l}\text { industry as share } \\
\text { of GDP }(\%)\end{array}\end{array}$ & 7,3 & 7,3 & 7,5 & 8,1 & 8,7 & 9,5 & 10,3 & 10,0 \\
\hline
\end{tabular}

Source: authorial computation based on Kunc (2015).

The construction industry in the Czech Republic recorded its best results in 2008, but since 2014 may be showing an improvement - for example, building production in 2015 increased by $5.5 \%$ (adjusted for working days, which grew by $5.6 \%$ ), building construction grew by $0.6 \%$ (contribution $+0.4 \mathrm{pp}$ ) and civil engineering output recorded an annual growth of construction output by $16.4 \%$ (contribution $+5.1 \mathrm{pp}$ ). The average nominal wage increased by $6.6 \%$ (Czech Statistical Office, 2014).

Also, management of staff in the building sector has specific characteristics (more Hajek 1999; Linkeschová, 2005; Atallah, 2006). There are problems with work ethic, high staff turnover, etc. Everything which was named above is influenced seasonally and by climatic conditions. (Linkeschová, 2005)

Some data of employment and wages in the building sector of the Czech Republic is shown in Tab. 2.

Tab. 2: Employment and wages in the construction industry in the Czech Republic in years 2000 - 2014

\begin{tabular}{|c|c|c|c|c|c|c|c|}
\hline \multirow{2}{*}{ Years } & \multirow{2}{*}{$\begin{array}{l}\text { Number } \\
\text { of active } \\
\text { subjects }\end{array}$} & \multicolumn{2}{|c|}{$\begin{array}{l}\text { Average number of } \\
\text { employees }\end{array}$} & \multicolumn{2}{|c|}{$\begin{array}{l}\text { Average registered } \\
\text { number of } \\
\text { employees }\end{array}$} & \multicolumn{2}{|c|}{$\begin{array}{l}\text { Average gross wages } \\
\text { for one month }\end{array}$} \\
\hline & & $\begin{array}{l}\text { Indivi- } \\
\text { dual }\end{array}$ & Year index & $\begin{array}{l}\text { Indivi- } \\
\text { dual }\end{array}$ & $\begin{array}{l}\text { Year } \\
\text { index }\end{array}$ & CZK & Year index \\
\hline 2000 & 137399 & 398878 & & 275674 & & 12499 & \\
\hline 2001 & 139004 & 395278 & 99,1 & 270880 & 98,3 & 13423 & 107,4 \\
\hline 2002 & 144028 & 380992 & 96,4 & 252589 & 93,2 & 14066 & 104,8 \\
\hline 2003 & 146921 & 384497 & 100,9 & 253593 & 100,4 & 15054 & 107,0 \\
\hline 2004 & 150043 & 392231 & 102,0 & 259080 & 102,2 & 16090 & 106,9 \\
\hline 2005 & 145379 & 394154 & 100,5 & 266492 & 102,9 & 16624 & 103,3 \\
\hline
\end{tabular}


European Financial and Accounting Journal, 2016, vol.11, no. 3, pp. 53-68.

\begin{tabular}{|c|c|c|c|c|c|c|c|}
\hline \multirow{2}{*}{ Years } & \multirow{2}{*}{$\begin{array}{l}\text { Number } \\
\text { of active } \\
\text { subjects }\end{array}$} & \multicolumn{2}{|c|}{$\begin{array}{l}\text { Average number of } \\
\text { employees }\end{array}$} & \multicolumn{2}{|c|}{$\begin{array}{l}\text { Average registered } \\
\text { number of } \\
\text { employees }\end{array}$} & \multicolumn{2}{|c|}{$\begin{array}{l}\text { Average gross wages } \\
\text { for one month }\end{array}$} \\
\hline & & $\begin{array}{l}\text { Indivi- } \\
\text { dual }\end{array}$ & Year index & $\begin{array}{l}\text { Indivi- } \\
\text { dual }\end{array}$ & $\begin{array}{l}\text { Year } \\
\text { index }\end{array}$ & CZK & Year index \\
\hline 2006 & 145953 & 402425 & 102,1 & 266899 & 100,2 & 17671 & 106,3 \\
\hline 2007 & 152753 & 406997 & 101,1 & 269417 & 100,9 & 18847 & 106,7 \\
\hline 2008 & 157312 & 410927 & 101,0 & 270516 & 100,4 & 20706 & 109,9 \\
\hline 2009 & 162224 & 402000 & 97,8 & 263458 & 97,4 & 21819 & 105,4 \\
\hline 2010 & 167032 & 405583 & 100,9 & 258353 & 98,1 & 21999 & 100,8 \\
\hline 2011 & 175758 & 396336 & 97,7 & 242395 & 93,8 & 22515 & 102,3 \\
\hline 2012 & 175799 & 393560 & 99,3 & 235911 & 97,3 & 22589 & 100,3 \\
\hline 2013 & 170482 & 374264 & 95,1 & 220533 & 93,5 & 22050 & 97,6 \\
\hline 2014 & 170210 & 364825 & 97,5 & 211730 & 96,0 & 22451 & 101,8 \\
\hline
\end{tabular}

Source: Czech Statistical Office (2016).

An important feature of the building companies in the Czech Republic is also the existence of tangible fixed and intangible assets or work in progress in the financial statements. The Czech construction industry is characterized by a large number of contractual relationships with many suppliers and customers; they are often used by subcontracting. Legal disputes with suppliers are also frequent in the building market. These problems are considered to be extra work, etc. (Hula, 2014)

\section{Payment discipline and bankruptcy models}

The lack of payment discipline, which is defined as late payment and debtors' failure to settle their liabilities, is a massive problem of many entrepreneurs (Commission of the European Communities, 2009).

Many reasons exist for delayed payments in research studies. The main of these reasons are the following: bad ethics of debt payment, dysfunctional relationships between business partners, lack of legal protection of payments, delayed payments by government budget, ineffective system of debt recovery, and bankruptcy of debtor (Masiukiewicz, 2016).

Salamon and Mesko (2013) discussed in their research papers, how one of the key reasons for the lack of payment discipline is poor business ethics and considering the results of their research, they suggest the improvement of payment dimensions by weakening of ethical climate. 
Liao and Mehdian (2016) mentioned, during the last six decades and, following the research papers by Beaver (1968) and Altman (1968), how a voluminous amount of literature has been developed in finance and accounting to measure financial distress and to predict the bankruptcy of companies (see for example Altman, 1973; Jones, 1987; Altman et al., 1994; Zmijewski, 1984; Beaver et al., 2005; Altman and Branch, 2015, Taffler, 1982; Agarwal and Taffler, 2008).

A great variety of models for diagnosis and prediction of the business financial situation is used. Many of these models are presented by application of foreign models which, when transformed to the Czech conditions, can cause many problems like absence of long time series data of financial indicators, problems of data validity, dynamical changes of social-economic environment etc. The bankruptcy models are indicators which are compiled on the basis of comparativeanalytical or mathematical-statistical methods. The bankruptcy models are used to diagnose the financial situation of a company, understand its financial health, or to predict the crisis development of the company (Sedláček, 2001).

Chapter methodology and data mentions how we have chosen these three indicators for our research:

- Index IN05: This index is an aggregate index of relative financial indicators, which reflects the profitability, indebtedness, solvency and liquidity of company activity. If the index value exceeds the threshold of 1.6, the company is rated as creditworthy. If the index falls below the limit of less than or equal to 0.9 , then the company is rated as bankruptcy, there is a so-called grey zone in the interval between the lower and upper limit. Neumaierová and Neumaier (2005) reported that this model has high explanatory power.

- Taffler's model indicates the probability of bankruptcy. This model was formed in 1977 by Professor R. J. Tafflerem. Companies with a value greater than 0.3 have a low probability of bankruptcy and companies with a value of less than 0.2 may be more likely to expect bankruptcy, see more Sedláček (2007), Strouhal (2011).

- Index IN99 is a creditworthy model constructed from the owner's perspective. According to Neumaierová and Neumaier (2002) index IN99 rather evaluates a firm's ability to generate economic profits for owners. If the index value is less than 0.683 , then the company does not create profit, however, if it is ranging from 0.684 to 1.088 , then the firm does not create profit. If the index value is between 1.089 and 1.419, then firm belongs to the so-called grey zone, if the index value is between 1.42 and 2.069 , then the firm is likely to create profit and if the index value is higher than 2.069, then company creates profit.

There is an abundance of research studies investigating the prediction ability of bankruptcy models. The first reason for using the above three models for subsequent analysis was mainly because the models are mostly used in the Czech 
Republic. And the second reason was the limitation of data in the database Bisnode. In response to the Altman analysis in 1977 the Taffler's model was established (see Taffler and Tisshaw, 1977). We considered this model mainly because of its simple mechanism of calculation. Throughout history, it had been turned out that the application of the Altman Z-score is not suitable for evaluation of financial pressure of Czech companies and, in these consequences, indexes "IN" have been originated. The modification IN99 is probably the most known, but many authors have discussed about the informative efficiency of the index IN99. Sedláček (2009) evaluates the informative efficiency of IN 99 for 85 percent, in the opposite; Synek (2007) concluded that informative efficiency of the IN99 is less than 50 percent. Machek (2014) confirmed the relatively high explanatory power of IN05 in comparison to IN99 and Taffler's model. The limitations of informative efficiency of the bankruptcy models are obvious, but we suppose that these three models are the most appropriate for our analysis.

\section{Data and methodology}

The data used for the analysis is drawn from the accounts of companies whose main economic activity by CZ-NACE belongs to a section F - Construction. Information about payment discipline is also used, which processes and provides the firm Bisnode in the form of a so-called payment index. This data as well as data from the financial statements is provided by the company Bisnode under license of database Albertina Gold Edition 6/2014.

According to the CZSO, the construction industry includes the following three divisions:

- 41 Construction of buildings

- 42 Civil engineering

- 43 Specialised construction activities

For the analysis, the years 2010 - 2014 were selected. The data set contains 1384 companies which have complete data from available financial statements for all 5 years in the reference period, i.e. basic data set contains 6920 observations. ${ }^{1}$ For assessing the financial situation of enterprises the following three bankruptcy models are used: IN05, Taffler's model and IN99.

From all three financial indicators, simple arithmetic averages are calculated for the entire reference period. It is also examined using a boxplot if the data set

1 If we compare the number of subjects in economy and number of analyzed companies we can conclude that there is a quite huge difference. The first reason is that the number of subjects from CZSO does not cover even only companies but contains also tradesman. The second reason is that the companies which are not required insert the financial statements in the Commercial Register, are not included and also not all company have available data for whole reference period. 
Kureková, L. - Hejduková, P.: Construction Industry and Payment Discipline in the Czech Republic.

contains extreme values. It is identified that outliers have occurred for all three financial indicators. Further outliers are also visually assessed in context with the other financial indicators of the companies and the data set is corrected (10 companies were dropped out from data set). Visualization of outliers may be seen in Figures 2, 3 and 4.

\section{Fig. 2: Identification of outliers - IN05}

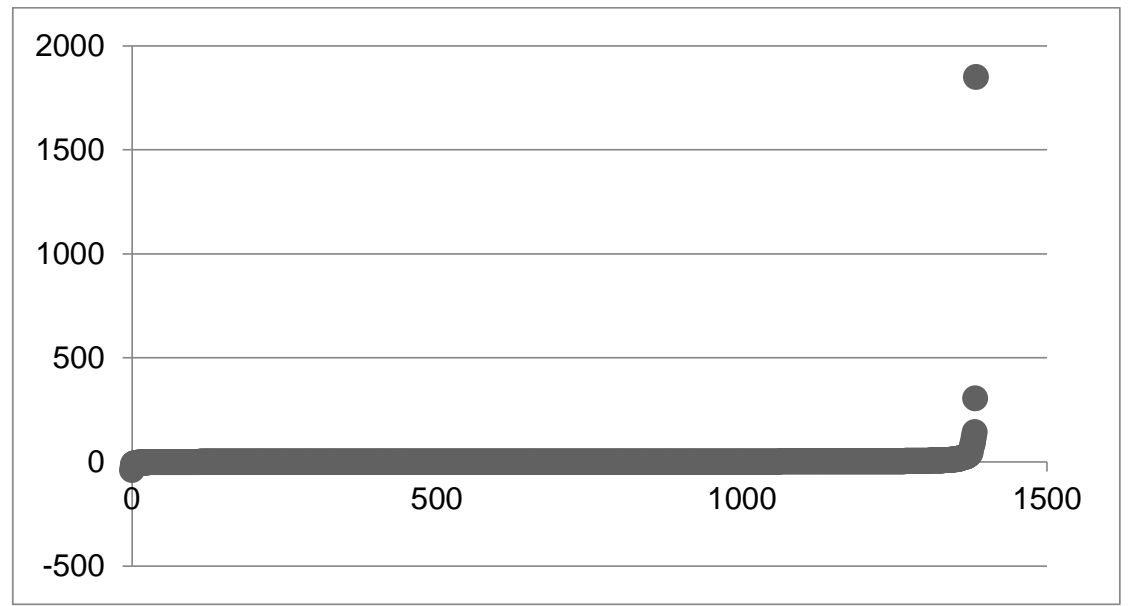

Source: authorial computation with using STATA 11.1.

\section{Fig. 3: Identification of outliers - TAFFLER}

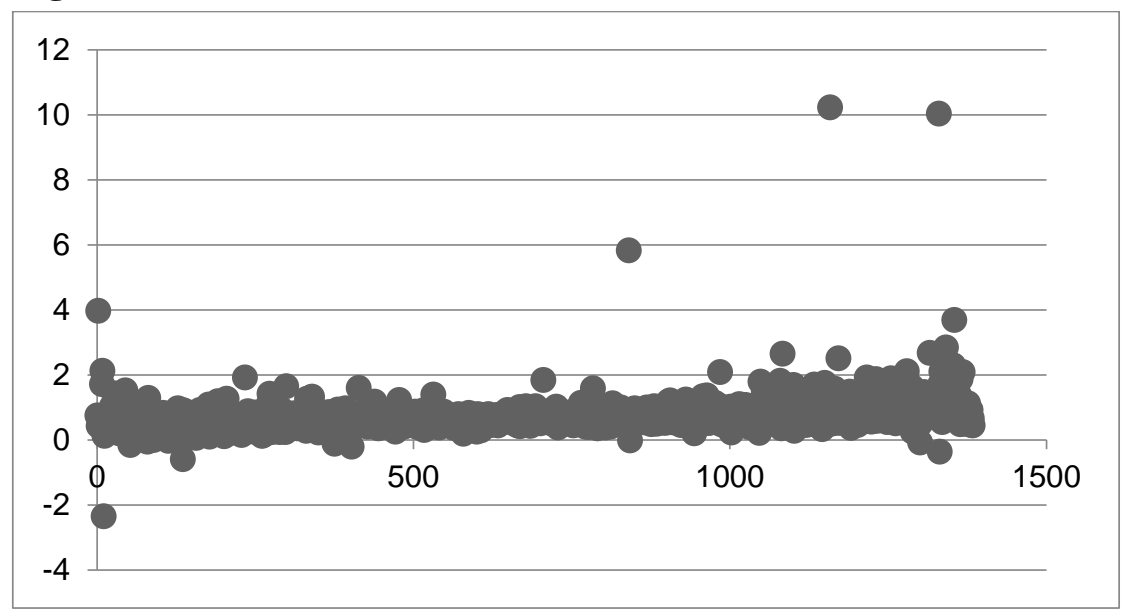

Source: authorial computation with using STATA 11.1. 
Fig. 4: Identification of outliers - IN99

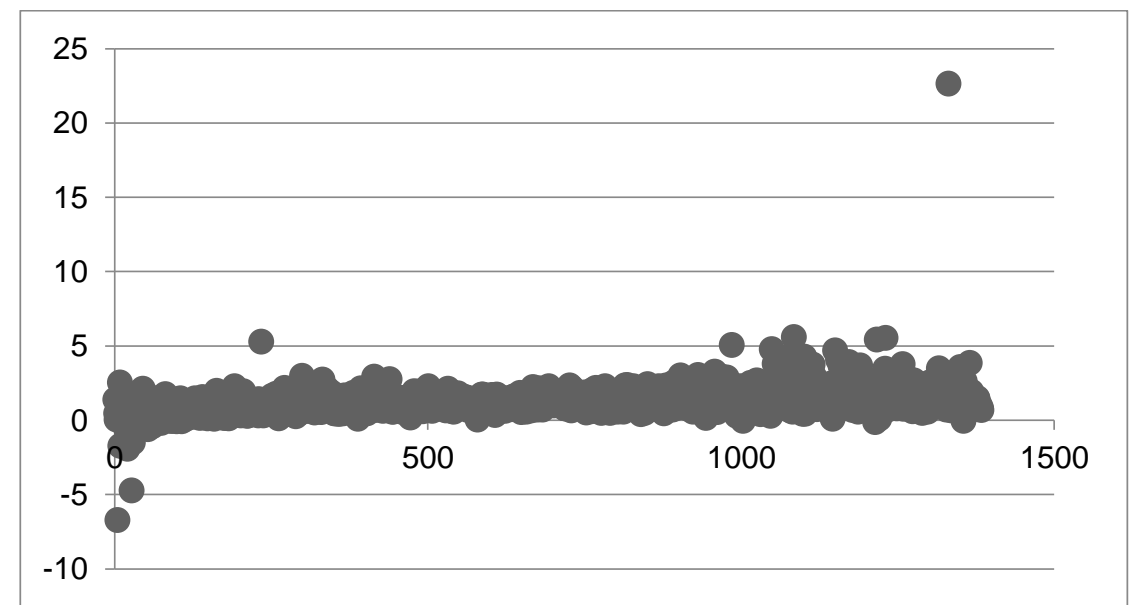

Source: authorial computation with using STATA 11.1.

Companies' payment discipline is expressed as a payment index, which is designed by Bisnode, and this payment index is continually updated based on information supplied directly by individual companies. Based on the assessment of individual payment discipline of the company, a payment index is calculated, which takes the form of rating marks similar to that used by international rating agencies. The basic source of data on payment discipline companies are invoices for goods sold or services rendered. For the purposes of this article, the scale of the company, Bisnode, is reduced to the three basic levels as well as performed by Špička (2014), see Tab. 3. Representation of enterprises in different groups, divided according to the modified payment index, is relatively unbalanced, as well as in the industrial sector, the vast majority of enterprises are in group "B", see Špička (2014).

\section{Tab. 3: Overview of the classification of payment discipline firms and distribution of the number of companies}

\begin{tabular}{llc}
\hline Payment index Bisnode & $\begin{array}{l}\text { Modified payment } \\
\text { index }\end{array}$ & $\begin{array}{l}\text { Number of } \\
\text { enterprises }\end{array}$ \\
\hline A- Pay on time & A & 403 \\
\hline B1- Pay just after maturity 1-4 & & \\
B2- Pay shortly after maturity 5-10 & B & 781 \\
B3-Pay average 11-20 & & \\
C1-Pay sufficiently 21-30 & & \\
\hline
\end{tabular}


Kureková, L. - Hejduková, P.: Construction Industry and Payment Discipline in the Czech Republic.

\begin{tabular}{llc}
\hline Payment index Bisnode & $\begin{array}{l}\text { Modified payment } \\
\text { index }\end{array}$ & $\begin{array}{l}\text { Number of } \\
\text { enterprises }\end{array}$ \\
\hline C2-Pay late 31-60 & & \\
C3-Pay very late 61-90 & C & \\
D- Pay extremely late 91-120 & & \\
E- Likely failure to pay 121 and more & & \\
\hline
\end{tabular}

Source: Bisnode, 2015, authorial modification.

The modified payment index is compared to bankruptcy models. As already mentioned, variations in size groups of companies divided according to a modified payment index are significant. This is one reason why it is not possible to use analysis of variance (ANOVA) for testing hypotheses. Assumption of the normal distribution of observed variables is not also satisfied, normality was verified by the Shapiro-Wilk test and it rejects the null hypothesis at the significance level of 0.05 for all variables, see Shapiro and Wilk (1965). Furthermore, the assumption of the equality of variances of each group is not valid, for verifying this assumption the Levene test of homogeneity of variance is used (see Levene 1960). Using the Levene test does not require compliance with the conditions of normality, unlike the Barttlet test (see Bartlett, 1937).

For the above reasons, it is necessary to make pairwise comparisons between groups of companies by the payment discipline, using the Kolmogorov-Smirnov test of the equality of continuous. It tests the hypothesis $\mathrm{H} 0: \mathrm{F}(\mathrm{x})=\mathrm{F} 0(\mathrm{x})$ against the alternative $\mathrm{H} 1$ : $\mathrm{F}(\mathrm{x}) \neq \mathrm{F} 0(\mathrm{x})$ for all $\mathrm{x}, \mathrm{F}(\mathrm{x})$ is the distribution function of the second sample data (Hendl, 2012). In total is formulated and then tested five hypotheses:

- H1: Index IN05 of companies with better payment discipline is significantly higher than the index IN05 of companies with a worse payment discipline.

- H2: Taffler's model of companies with better payment discipline is significantly higher than the Taffler's model of companies with a worse payment discipline.

- H3: Index IN99 of companies with better payment discipline is significantly higher than the index IN99 of companies with a worse payment discipline.

- H4: Firm size (measured by number of employees) of companies with better payment discipline is significantly higher than the firm size of companies with a worse payment discipline.

- H5: Old age (measured as the number of years a company's market) of companies with better payment discipline is significantly higher than the old age of companies with a worse payment discipline. 
Note that it is not necessary to use the K-S test to define dependent and independent variables, and this test allows one to find evidence for the associations of given variables, and direction of influence is not specific and could be in both directions. We will suppose that influence of variable payment discipline on selected variables is minor and that this variable is likely dependent on variables: in05, taffler, in99, empl and old.

\section{Results}

At first, there are basic descriptive statistics of variables, see Tab. 4. The group of companies with a modified payment index. "A" has on average, the highest levels for all three financial indicators. On average, the smallest companies also occur in group "A". According to the descriptive statistics, it can be said that the groups in its average age do not differ greatly, the biggest difference between the groups in average age is 0.81 years (i.e. between groups $\mathrm{A}$ and $\mathrm{B}$ ).

\section{Tab. 4: Summary statistics}

\begin{tabular}{rllllrr}
\hline & & in05 & taffler & in99 & \multicolumn{1}{c}{ empl } & \multicolumn{1}{c}{ old } \\
\hline \multirow{4}{*}{$\mathrm{A}$} & mean & 2.598 & 0.754 & 1.285 & 26.177 & 15.931 \\
& med & 1.299 & 0.668 & 1.175 & 12.0 & 16.0 \\
& sd & 7.355 & 0.461 & 0.800 & 80.422 & 5.973 \\
& mean & 2.379 & 0.690 & 1.234 & 53.088 & 16.741 \\
B & med & 1.194 & 0.642 & 1.143 & 15.0 & 17.0 \\
& sd & 8.669 & 0.309 & 0.702 & 184.553 & 6.000 \\
& mean & 1.544 & 0.618 & 1.034 & 36.691 & 16.295 \\
C & med & 0.882 & 0.591 & 0.935 & 15.0 & 16.0 \\
& sd & 5.927 & 0.248 & 0.666 & 76.920 & 5.628 \\
\hline
\end{tabular}

Source: authorial computation with using STATA 11.1

Tab. 5 contains the results of Kolmogorov-Smirnov test of the equality of continuous for examined variables (bankruptcy models, size and old age of the company). 
Kureková, L. - Hejduková, P.: Construction Industry and Payment Discipline in the Czech Republic.

Tab. 5: The results of statistical comparison of companies according to payment discipline

\begin{tabular}{llllll}
\hline & H1 & H2 & H3 & H4 & H5 \\
\hline A vs. B & $\mathrm{A}>\mathrm{B}$ & $\mathrm{A}>\mathrm{B}$ & $\mathrm{A}>\mathrm{B}$ & $\mathrm{A}<\mathrm{B}$ & $\mathrm{A}<\mathrm{B}$ \\
sig. & $* *$ & $* * *$ & $* * *$ & $* * *$ & $*$ \\
B vs. C & $\mathrm{B}>\mathrm{C}$ & $\mathrm{B}>\mathrm{C}$ & $\mathrm{B}>\mathrm{C}$ & null H & null H \\
sig. & $* * *$ & $* * *$ & $* * *$ & - & - \\
A vs. C & $\mathrm{A}>\mathrm{C}$ & $\mathrm{A}>\mathrm{C}$ & $\mathrm{A}>\mathrm{C}$ & $\mathrm{A}<\mathrm{C}$ & null H \\
sig. & $* * *$ & $* * *$ & $* * *$ & $* * *$ & - \\
\hline
\end{tabular}

Source: authorial computation with using STATA 11.1.

Note: sig.: $* 0,1 * * 0,05 * * * 0,001$.

According to the results of the Kolmogorov-Smirnov test of the equality of continuous, one may accept the assumption that companies with better payment habits have significantly higher indicators of credibility than firms with poor payment discipline. Companies on average with fewer employees have better payment discipline, it can be assumed that smaller firms have a better payment discipline than companies with more employees and vice versa. The difference in the average old age of companies is minimal and a null hypothesis was rejected only once ("A" vs. "B") at the significance level of 0.1 , therefore is not possible to say that companies with a longer history on market have better payment discipline.

The aggregate index IN05 shows that companies with better payment habits have better financial health. Authors Čámská and Hájek (2012) and Machek (2014) confirm the relatively high explanatory power of index IN05 for Czech companies. Therefore, index IN05 is chosen for a more detailed rendering of the financial situation of construction companies on the market in relation to payment discipline (see Tab. 6).

Tab. 6: Distribution of companies according to payment discipline and index IN05

\begin{tabular}{lrrrr}
\hline $\begin{array}{l}\text { Payment } \\
\text { index/IN05 }\end{array}$ & Bankrupcy & Creditworthy & Grey zone & Total \\
\hline $\mathrm{A}$ & $9.17 \%$ & $11.64 \%$ & $8.52 \%$ & $29.33 \%$ \\
$\mathrm{~B}$ & $19.21 \%$ & $18.34 \%$ & $19.29 \%$ & $56.84 \%$ \\
$\mathrm{C}$ & $6.91 \%$ & $2.18 \%$ & $4.73 \%$ & $13.83 \%$ \\
\hline Total & $\mathbf{3 5 . 3 0 \%}$ & $\mathbf{3 2 . 1 7 \%}$ & $\mathbf{3 2 . 5 3 \%}$ & $\mathbf{1 0 0 . 0 0 \%}$ \\
\hline
\end{tabular}

Source: Bisnode, 2015, authorial modification. 
Tab. 6 shows that the payment discipline of companies in the construction industry is relatively good. Nearly $86 \%$ of companies are evaluated properly as above average or average by the payment index, i.e. companies pay their obligations no later than 30 days overdue. The dataset is a total of $32.17 \%$ of creditworthy companies. Almost a third (30\%) of creditworthy companies are evaluated properly as above average or average by the payment index. Only $2.18 \%$ of the companies were, on average, during the years 2010-2014, evaluated as creditworthy and are measured by the modified payment index "C". This group theoretically operates with relatively good financial health, but the payment discipline of these companies is below average. In the group of bankruptcy companies (35.3\% of total), companies with modified payment index " $\mathrm{B}$ " are rated the most, and least of all are companies which received the assessment " $\mathrm{C}$ ". Tab. 6 also shows that there are companies with relatively good financial health and poor payment practices $(2.18 \%)$ and companies that aim to bankruptcy, but they have good payment discipline $(9.17 \%)$.

\section{Conclusion}

The aim of this paper was to identify, compare and evaluate the financial situation of building companies with different payment practices in the Czech Republic in the period $2010-2014$. The results are based on an analysis of 1374 companies operating in the construction industry and on data on their payment discipline processed by Bisnode.

The results of the testing of hypotheses show that subjects with better payment habits have a higher index IN05 (H1), higher Taffler's model (H2), higher index IN99 (H3). It can be assumed that better financial health contributes to better payment habits of Czech construction firms. Next, findings show that subjects with better payment habits have a lower number of employees (H4). It can be assumed that the relatively large firms, given their position at the market, afford to pay overdue invoices, but not longer than the limit of 30 days. It has not been a confirmed assumption that the old age of the companies with better payment habits is significantly higher than that of companies with poor payment discipline (H5).

Two extremes were identified. On the one hand, there are companies, which have a payment index below average up to extremely bad, and these companies pay their obligations for more than 30 days overdue, but this group has good financial health of companies and quite high index IN05 (2.18\% of total). This group is very small, but these enterprises could represent a high risk to their suppliers. On the other hand, there are companies with relatively poor financial health and a high probability of bankruptcy, which pays its obligations due at maturity $(9.17 \%$ of total). 
The paper shows as well as Špička (2014), that bankruptcy models can be an effective tool for assessing and predicting the financial situation of the companies, but to illustrate the behaviour of firms in exchange relationships, it is advisable to use an additional indicator, which is classified by payment discipline rating.

The possible extension of this study could be a closer examination of the causes of the above mentioned extreme cases and their risk assessment for suppliers.

\section{References}

Agarwal, V., Taffler, R. J., 2008. Comparing the Performance of Market-based and Accounting-based Bankruptcy Prediction Models. Journal of Banking \& Finance 8, 1541-1551. DOI: 10.1016/j.jbankfin.2007.07.014.

Altman, E. I., 1968. Financial Ratios, Discriminant Analysis and the Prediction of Corporate Bankruptcy. Journal of Finance 4, 589-609. DOI: 10.2307/2978933.

Altman, E. I., 1973. Predicting Railroad Bankruptcies in America. The Bell Journal of Economics and Management. Journal of Finance 4, 184-211, $10.2307 / 3003144$.

Altman, E. I., Branch, B., 2015. The Bankruptcy System's Chapter 22 Recidivism Problem: How Serious is it. The Financial Review 1, 1-26. DOI: 10.1111/ fire.12058.

Altman, E. I., Marco, G., Varetto, F., 1994. Corporate Distress Diagnosis: Comparisons Using Linear Discriminant Analysis and Neural Network: The Italian Experience. Journal of Banking and Finance 3, 505-529. DOI: 10.1016/0378-4266(94)90007-8.

Atallah, P. W., 2006. Building a successful construction company. Chicago, Dearborn Trade, A Kaplan Professional Company.

Bartlett, M. S., 1937. Properties of sufficiency and statistical tests. Proceedings of the Royal Society, series A 901, 268-282. DOI: 10.1098/rspa.1937.0109.

Beaver, W. H., 1968. Market Prices, Financial Ratios, and the Prediction of Failure. Journal of Accounting Research 2, 179-192. DOI: 10.2307/2490233.

Beaver, W. H., McNichols, M. F., Rhie, J. W., 2005. Have Financial Statements Become Less Informative? Market Prices, Financial Ratios Less Informative? Evidence from the Ability of Financial Ratio to Predict Bankruptcy. Review of Accounting Studies 1, 93-122. DOI: 10.1007/s11142-004-6341-9.

Bisnode, 2014. Platební morálka ve stavebnictví. Available from: <http://www.bisnode.cz/novinky/infografika-platebni-moralka-ve-stavebnictvi/>. [26 February 2016].

Bisnode. Databáze Albertina Gold Edition CZ. 
Čámská, D., Hájek, J., 2012. Companies related to the glass making industry and their financial health. In Kislingerová, E., Špička, J. (ed.): Transakční náklady českých ekonomických subjektů v insolvenčním řízení, možnosti jejich snižování a zlepšení statistiky insolvenčních řízení. Česká národní banka: Praha, Oeconomica.

Český statistický úr̆ad (Czech Statistical Office), 2016. Stavebnictví - prosinec 2015. Available from: <https://www.czso.cz/csu/czso/cri/stavebnictvi-prosinec2015>. [19 February 2016].

Český statistický úřad. (Czech Statistical Office), 2014. Jak se daří českému stavebnictví. Available from: <https://www.czso.cz/csu/czso/jak-se-dari-ceskemustavebnictvi-2014-k2r7grd9zu>. [13 February 2016].

Commission of the European Communities, 2009. Commission staff working document - Accompanying document to the Proposal for a Directive of the European parliament of the council on combating late payment in commercial transactions. Available from: <http://eurlex.europa.eu/LexUriServ.do?uri= SEC:2009:0315:FIN:EN:PDF>. [1 March 2013].

Hendl, J., 2012. Přehled statistických metod: analýza a metaanalýza dat. Praha, Portál.

Hula, J., 2014. Specifika účetní závěrky a jejího auditu u stavebních společností. Účetní kavárna. Available from: <http://www.ucetnikavarna.cz/archiv/dokument/ doc-d43152v54331-specifika-ucetni-zaverky-a-jejiho-auditu-u-stavebnichspolecnosti/>. [12 February 2016].

Jones, F. L., 1987. Current Techniques in Bankruptcy Prediction. Journal of Accounting Literature 6, 131-164.

Kunc, Z., 2015. Vývoj stavebnictví rok 2010-2014. Stavebnictví České republiky. Available from: 〈http://www.mpostav.cz>. [14 February 2016].

Levene, H., 1960. Robust tests for equality of variances. In Olkin, I., Ghurye, S. G., Hoeffding, W., Madow, W. G., Mann, H. B. (ed.): Contributions to Probability and Statistics: Essays in Honor of Harold Hotelling. Stanford, Stanford University Press. DOI: 10.1002/bimj.19630050119.

Liao, Q., Mehdian, S., 2016. Measuring financial distress and predicting corporate bankruptcy: an index approach. Review of Economic \& Business Studies 17, 3351. DOI: $10.1515 /$ rebs-2016-0024.

Linkeschová, D., 2005. K otázkám managementu ve stavebnictví. Brno, Akademické nakladatelství CERM.

Machek, O., 2014. Long-term Predictive Ability of Bankruptcy Models in the Czech Republic: Evidence from 2007-2012. Central European Business Review 2, 4-17. DOI: $10.18267 /$ j.cebr.80. 
Machková, H., 2015. Mezinárodní marketing. Praha, Grada Publishing.

Masiukiewicz, P., 2016. Payments in business, Eureopean payment index. Journal of applied management and investments 3, 166-173.

McGeorge, D., Zou, P., Palmer, A., 2013. Construction management: new directions. Chichester, John Willey \& Sons, Ltd.

Neumaierová, I., Neumaier, I., 2002. Výkonnost a tržní hodnota firmy. Praha, Grada.

Neumaierová, I., Neumaier, I., 2005. Index IN05. In Červinek, P. (ed.) Evropské finanční systémy 2005. Brno, Masarykova univerzita.

Perthen, E., 2015. Správa a vymáhání pohledávek. Praha, Wolters Kluwer a.s.

Pleskač, J., Soukup, L., 2001. Marketing ve stavebnictví. Praha, Grada Publishing. Salamon, T., Mesko, M., 2016. Can an Ethical Work Climate Influence Payment Discipline? Journal of Industrial Engineering and Management 1, 73-89. DOI: 10.3926/jiem.1537.

Sedláček, J., 2007. Finanční analýza podniku. Brno, Computer Press.

Sedláček, J., 2009. Finanční analýza podniku. Computer Press, Brno.

Sedláček, J., 2001. Účetní data v rukou manažera - finanční analýza v řízení firmy. Computer Presss, Praha.

Shapiro, S. S., Wilk, M. B., 1965. An analysis of variance test for normality (complete samples). Biometrika 3-4, 591-611. DOI: 10.1093/biomet/52.3-4.591.

Špička, J., 2014. Platební morálka strojírenských firem v ČR. Ekonomika a management 2.

Strouhal, J., 2011. Účetní závěrka. Praha, Wolters Kluwer.

Synek, M. a kol., 2007. Manažerská ekonomika. Praha, Grada Publishing.

Taffler R. J., Tisshaw, H., 1977. Going, going, gone - four factors which predict. Accountancy 8, 50-54.

Taffler, R. J., 1982. Forecasting Company Failure in the UK Using Discriminant Analysis and Financial Ratio Data. Journal of the Royal Statistical Society, series A $145,342-358$. DOI: $10.2307 / 2981867$.

Zmijewski, M. E., 1984. Methodological Issues Related to the Estimation of Financial Distress Prediction Models. Journal of Accounting Research 22, 59-82. DOI: $10.2307 / 2490859$. 